\title{
Low Dose Theophylline and Tiotropium Rotacap as Add on Therapy in COPD Patients-Clinical Trial
}

Muzna Hameed Dar, Syed Mehboob Alam, Qurrat ul Ain Bukhari, Kauser Ismail, Syed Azhar Hussain Zaidi

ABSTRACT:

Objectives: To compare the role of low dose Theophylline and Tiotropium rotacap in improving the lung functions and day to day life of patients suffering from COPD.

Study Design and Setting: A Clinical trial study was conducted at Department of Pharmacology and Therapeutics, BMSI in association with Department of Chest Medicine, JPMC.

Methodology: This study was planned as an open label and parallel clinical trial study. A total of 168 patients of COPD were selected for this study and only 161 patients completed the 3 months duration of the study. The enrolled patients were grouped into 2, namely A and B. Tab. Theophylline $350 \mathrm{mg}$ was given to Group A in two divided doses while Tiotropium rotacap $18 \mu \mathrm{g}$ through rotahaler was given to group B once a day.

Results: Mean FEV1 \pm SD was improved by $0.04 \pm 0.02$ in Theophylline therapy group while by $0.07 \pm 0.01$ in the Tiotropium therapy treated group and a significant difference between the changes in the two treatment groups was evident. There was a percentage improvement in PEFR of $8.9 \pm 5.8$ in the Theophylline therapy treated group and of $13.2 \pm 4.7$ in Tiotropium therapy treated group. When Tiotropium group was compared with Theophylline group for improvement in percentage change in PEFR from day 0 , a significant difference was evident between the two groups. There was a significant improvement from day 0 in CAT score in Tiotropium treated groups versus Theophylline group after 3 months of therapy.

Conclusion: Tiotropium rotacap was more effective as compared to low dose Theophylline in improving pulmonary functions and CAT score in patients with COPD.

Keywords: COPD, CAT score, FEV1, FVC, Health related quality of life, PEFR, Theophylline, Tiotropium.

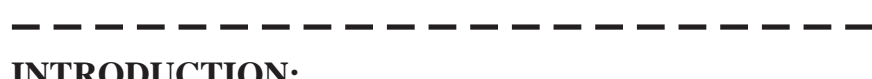

INTRODUCTION:

COPD (Chronic Obstructive Pulmonary Disease) is an alarming issue being the third highest mortality reason worldwide by the year 2030. ${ }^{1}$ In Pakistan, it has an estimated death rate of 71 per 100,000 . This problem needs to be addressed efficiently for being the fourth highest among the 25 most populated countries on the globe. It has been a great problem to provide medical access to patients of low socioeconomic status. ${ }^{3}$ Risk for COPD is related to age, genetic make-up, decrease in maximally achieved pulmonary functions, previous pulmonary tract infections, chronic

\begin{tabular}{|c|}
\hline $\begin{array}{l}\text { Muzna Hameed Dar } \\
\text { Senior Lecturer, Department of Pharmacology, } \\
\text { BMSI, JPMC, Karachi } \\
\text { Email: drmuznadar@yahoo.com }\end{array}$ \\
\hline $\begin{array}{l}\text { Syed Mahboob Alam } \\
\text { Associate Professor, Department of Pharmacology, } \\
\text { BMSI, JPMC, Karachi }\end{array}$ \\
\hline $\begin{array}{l}\text { Qurrat ul Ain Bukhari } \\
\text { Senior Lecturer, Department of Pharmacology, } \\
\text { SSCMS, Karachi }\end{array}$ \\
\hline $\begin{array}{l}\text { Kauser Ismail } \\
\text { Assistant Professor, Department of Pharmacology, } \\
\text { Ziauddin Medical College, Karachi }\end{array}$ \\
\hline $\begin{array}{l}\text { Syed Azhar Hussain Zaidi } \\
\text { Assistant Professor, Department of Pharmacology, } \\
\text { BUMHS, Quetta }\end{array}$ \\
\hline $\begin{array}{l}\text { Received: 02-Jan-2020 } \\
\text { Accepted: 07-Apr-2020 }\end{array}$ \\
\hline
\end{tabular}

asthma, exposure to air pollutants and smoking. ${ }^{4}$ Patient presents with chronic and progressive complain of shortness of breath, cough, phlegm production plus chest tightness. ${ }^{5}$ The occurrence of COPD needs to be established by carrying out spirometry. ${ }^{6}$ The criterion for labelling a patient with COPD is post-bronchodilator Forced expiratory volume (FEV1), forced vital capacity (FVC) less than $0.7 .^{7}$ Treatment with bronchodilators shows a principal effect by successfully decreasing airflow limitation and symptoms, hereby, improving health condition. They also lessen the number of exacerbations. ${ }^{8}$ Inhaled long acting $\beta 2$-agonists as well as anticholinergics are the most commonly prescribed drugs for relieving symptoms of COPD patients. ${ }^{9,}{ }^{10,11}$ In Triple therapy long acting muscarinic antagonist (LAMS) is added to patients already on long acting â agonist/Inhaled corticosteroid (LABA/ICS) to improve their health related quality of life. $^{12}$

Symptoms of COPD can mainly be reversed by decreasing the parasympathetic tone of airway smooth muscles. This target is achieved by parasympatholytic drugs that bind to muscarinic receptors, reverses bronchoconstriction and improves airflow to lungs. ${ }^{13}$ The extract from cigarette smoke causes release of interleukin- 8 from airway myocytes. The cholinergic receptors regulate this secretion as well. ${ }^{14}$ Tiotropium selectivity binds to M3 receptors. These muscarinic receptors are present on airway smooth myocytes and submucosal glands. Tiotropium, by binding to M3 receptors, causes decreased contraction of airway myocytes 
along with reduced mucus secretion and then a bronchodilator effect is achieved. ${ }^{15}$

Theophylline acts by nonselective inhibition of phosphodiesterase, thereby, producing bronchodilation. It moreover exhibits non-bronchodilator properties. When it is given at low plasma levels of $10 \mathrm{mg} / \mathrm{l}$, it only acts as a mild nonselective inhibitor of phosphodiesterase and, thereby, clinically significant bronchodilation is not achieved ${ }^{16}$. Low doses of theophylline activate histone deacetylases (HDACs). ${ }^{17}$ Therefore, at this low dose, significant antiinflammatory effect and reversal of steroid resistance has been evident. ${ }^{18}$ In this background, there is a strong need of studying the efficacy of Theophylline in reversing steroid resistance and its effect on health of a patient as an add on therapy as compared to addition of a bronchodilator, Tiotropium.

\section{METHODOLOGY:}

This study was planned as an open label and parallel group clinical trial study. It was conducted in the Department of Pharmacology and Therapeutics, BMSI in association with Department of Chest Medicine, JPMC; after taking approval from the ethical committee of JPMC.

Diagnosed patients with moderate to severe COPD disease (FEV1 $30 \%$ to $80 \%$ of normal according to GOLD classification of COPD) ${ }^{19}$ of both sex and ages > 35yrs were included in this study. Patients with history of exacerbation of COPD or else pulmonary tract infection in preceding 1 month, asthma, tuberculosis, pneumoconiosis, bronchiectasis, old interstitial pneumonia, history of lung cancers or resection, administration of supplemental oxygen for $>12$ hours a day, moderate to severe $\mathrm{BPH}$, deranged hepatic and renal functions, arrhythmias or cardiac failure were excluded from this study. Each patient gave written permission before being enrolled in the study. The study was conducted for 3 months with follow up appointments every fortnightly. Patients continued taking their Budesonide and Formoterol combination inhaler. Inhaler method was checked in each patient before commencing the study. We selected 168 COPD patients for this study but only 161 patients completed the 3 months duration of study. We randomly divided the enrolled patients into 2 groups in 1:1 ratio. Tab. Theophylline $350 \mathrm{mg}$ was prescribed to COPD patients in group A in two divided doses while Tiotropiumrotacap18 $\mu \mathrm{g}$ through rotahaler to group B once a day. Patients were taught to place Tiotropiumrota capsule in a hole in the rotahaler with its clear end upside. Twisting the barrel of rotahaler resulted in splitting of capsule. The patients inspired deeply and quickly while placing lips around the mouthpiece and then held their breath for 10 seconds after removing the mouthpiece.

Forced expiratory volume in $1 \mathrm{sec}$ (FEV1), forced vital capacity (FVC), Peak expiratory flow rate (PEFR) and chronic obstructive pulmonary disease assessment test (CAT) score were observed at day 0 and at day 91 of the study. ${ }^{21} \mathrm{CAT}$ score is based on eight different COPD related symptoms of patients. It uses a range from 0-40 to assess improvement in patient's quality of life. A decrease in score indicates improvement in symptoms and condition of patient. ${ }^{22}$

Computer program open epi version 2 was used to calculate sample size for our study. SPSS version 17 was used for data compilation and analysis. Chi-square test was to compare qualitative variables (gender, grading of disease, smoking history) and ANOVA to quantitative ones (Age, FEV1, FVC, PEFR and CAT score).

\section{RESULTS:}

Both groups were statistically comparable at baseline as shown in table 1 . When the change from day 0 in mean \pm SD of FEV1 in the Theophylline treated group $(0.04 \pm 0.02)$ and that of Tiotropium treated group $(0.07 \pm 0.01)$ were compared, a significant difference was observed between the two treated groups indicating that Tiotropium more effectively improved FEV1 in patients with COPD.

Mean improvement in FVC in Tiotropium treated group $(0.12 \pm 0.03)$ in comparison with Theophylline treated group $(0.06 \pm 0.03)$ was also significant, $\mathrm{P}$ value was 0.001 as shown in table 2 .

Improvement in percentage of PEFR $(1 / \mathrm{min})$ from day 0 was $8.9 \pm 5.8$ in the Theophylline therapy treated group and was $13.2 \pm 4.7$ in Tiotropium group. Percentage change in PEFR from baseline in Tiotropium group in comparison with Theophylline group was statistically significant. Tiotropium was more effective than Theophylline in improving PEFR.

When improvement in CAT score was compared in Theophylline group and Tiotropium group, a significant difference was evident between the two treated groups, Tiotropium showed more efficacy in improving the health status of patients. Change in mean \pm SD of CAT score in Theophylline treated group was found to be $1.8 \pm 1.14$ while in Tiotropium therapy treated group was found as $2.7 \pm 0.82$ on the completion of study.

\section{DISCUSSION:}

According to author's information, this was the first study in which the effectiveness of Theophylline was studied in comparison to Tiotropium as an add on therapy in terms of improving symptoms of patients with COPD. We find studies in which efficacy of low dose theophylline and Tiotropiumas add on therapies were studied ${ }^{21,22}$ but we could not find any study in which their efficacy as an add on therapy is compared.

According to studies of Barnes et al, Histone deacetylase 2 (HDAC2) is activated because of oxidative stress in COPD patients. HDAC 2 has a role in suppressing expression of inflammatory genes. Moreover, glucocorticoid treatment deactivates the activated inflammatory genes through HDAC 
Muzna Hameed Dar, Syed Mehboob Alam, Qurrat ul Ain Bukhari, Kauser Ismail, Syed Azhar Hussain Zaidi

Table No 1: Comparison of baseline characteristics between theophylline and tiotropium

\begin{tabular}{|l|c|c|c|}
\hline & $\begin{array}{c}\text { Theophylline group } \\
(\mathbf{n = 8 0})\end{array}$ & $\begin{array}{c}\text { Tiotropium group } \\
(\mathbf{n = 8 1})\end{array}$ & P value \\
\hline Age in years (Mean+S.D) & $59.1 \pm 8.07$ & $58.8 \pm 8.40$ & 0.804 \\
\hline Gender & & & \\
\hline Male & $78(97.5 \%)$ & $78(96.3 \%)$ & \multirow{2}{*}{0.66} \\
\hline Female & $2(2.5 \%)$ & $3(3.7 \%)$ & 0.66 \\
\hline Smokers & $78(97.5 \%)$ & $78(96.3 \%)$ & 0.942 \\
\hline Moderate COPD & $43(53.8 \%)$ & $44(54.3 \%)$ & 0.942 \\
\hline Female & $2(2.5 \%)$ & $3(3.7 \%)$ & 0.942 \\
\hline CAT score & $17.7 \pm 3.91$ & $17.9 \pm 3.34$ & 0.812 \\
\hline FEV1 & $1.14 \pm 0.24$ & $1.17 \pm 0.25$ & 0.480 \\
\hline FVC & $2.27 \pm 0.29$ & $2.29 \pm 0.35$ & 0.674 \\
\hline PEFR & $184 \pm 40.2$ & $188 \pm 39.3$ & 0.586 \\
\hline
\end{tabular}

Table No 2: Comparison of FEV1, FVC and PEFR between theophylline and tiotropium therapy treated COPD patients

\begin{tabular}{|c|c|c|c|c|}
\hline Sr. No. & & $\begin{array}{c}\text { Theophylline group } \\
(\mathrm{n}=\mathbf{8 0})\end{array}$ & $\begin{array}{c}\text { Tiotropium group } \\
(\mathrm{n}=\mathbf{8 1})\end{array}$ & P-value \\
\hline 1. & \multicolumn{4}{|l|}{ FEV1 (L) } \\
\hline a) & Day 0 & $1.14 \pm 0.24$ & $1.17 \pm 0.25$ & 0.477 \\
\hline b) & Day 91 & $1.18 \pm 0.24$ & $1.24 \pm 0.27$ & 0.125 \\
\hline c) & Change from baseline & $0.04 \pm 0.02$ & $0.07 \pm 001$ & 0.001 \\
\hline 2. & \multicolumn{4}{|l|}{$\mathrm{FVC}(\mathrm{L})$} \\
\hline a) & Day 0 & $2.27 \pm 0.29$ & $2.29 \pm 0.35$ & 0.681 \\
\hline b) & Day 91 & $2.32 \pm 0.29$ & $2.41 \pm 0.35$ & 0.098 \\
\hline c) & Change from baseline & $0.06 \pm 0.03$ & $0.12 \pm 0.03$ & 0.001 \\
\hline 3. & \multicolumn{4}{|l|}{ PEFR (L/min) } \\
\hline a) & Day 0 & $185 \pm 40.2$ & $188 \pm 39.3$ & 0.582 \\
\hline b) & Day 91 & $201 \pm 42.4$ & $212 \pm 40.6$ & 0.085 \\
\hline c) & \%age change from baseline & $8.9 \pm 5.8$ & $13.2 \pm 4.7$ & 0.001 \\
\hline 4. & \multicolumn{4}{|l|}{ CAT Score $($ Mean \pm SD) } \\
\hline a) & Day 0 & $17.7 \pm 3.91$ & $17.9 \pm 3.34$ & 0.808 \\
\hline b) & Day 91 & $16.0 \pm 3.85$ & $15.2 \pm 3.72$ & 0.202 \\
\hline c) & Change from baseline & $1.8 \pm 1.14$ & $2.7 \pm 0.82$ & 0.001 \\
\hline
\end{tabular}

2. Low dose Theophylline restores HDAC2 at molecular level through selective inhibition of phosphoinositide 3kinase-ä. ${ }^{23-24}$ This mechanism may explain improvement in FEV1, FVC and FEV1/FVC.

BREATH Trial by Bella et al. supports results of our study. In this randomized and multicenter study, effectiveness of oxitropium bromide was analyzed in comparison with theophylline and its combination with theophylline in patients with COPD. FEV1 and FVC were improved in all groups ${ }^{25}$. This supports the improvement in FEV1 and FVC seen in Theophylline treated group in our study.

Effect of Theophylline on health related quality of life was evaluated in terms of improvement in CAT score in comparison to earlier studies in which other different questionnaire were used to analyze health related quality of life (HRQoL) in COPD patients. A decrease of minimum 2 scores in CAT score is the criteria to be labelled as clinically significant improvement. In our study Theophylline did not cause any clinically significant improvement in CAT score. ${ }^{23}$ This result is supported by the study of Devereux who used low-dose theophylline in comparison with placebo and the number of COPD exacerbations was not decreased during 1 -year period. ${ }^{26}$

An increase in mean FEV1 of $0.07 \pm 001$ was evident in Tiotropium therapy treated patients. This result was in accordance with that of a 12 week SPRuCE study. In this multi-center, randomized study, effectiveness of Tiotropium was compared with placebo. Capsule Tiotropium $18 \mu \mathrm{g}$ through handihaler device was given as an additional therapy to COPD patients. Mean FEV1 was improved by 0.06 in Tiotropium treated group as compared to placebo on completion of the study. An increase in mean FVC was also 
significant in our study and was in accordance with the results of SPRUCE study. ${ }^{27}$

In UPLIFT trial, efficacy of Tiotropium was studied in terms of SGRQ score. In this trial, a same dose of Tiotropium that is $18 \mu \mathrm{g}$ was given through handihaler device in higher proportion of Tiotropium therapy treated patients. An improvement of 4 scores was seen in the treated patients. This is a clinically meaningful improvement in health related quality of life. ${ }^{28}$ This supports the results of our study in which a clinically significant decrease of $2.7 \pm 0.82$ in mean CAT score was evident at the end of study.

A study by Ford et al contradicts the results of our study. The results of his study showed that there was a significant decrease in the number of exacerbations in COPD patients when low dose Theophylline was given with inhaled corticosteroids as compared to when given alone. ${ }^{29}$ Therefore, more research is needed to establish the significance of adding low dose Theophylline in COPD patients to improve their quality of life. The limitations of the study were the nature of the study from only one center which represented limited population. This study followed patient for only 3 months that was a very short period to comment on number of exacerbations and adverse effects.

\section{CONCLUSION:}

Tiotropium rotacap was more effective in terms of improving pulmonary functions as well as health related quality of life in COPD patients when compared with low dose Theophylline.

\section{REFERENCES:}

1. World Health Report. Geneva: World Health Organization. Available from URL: http://www.who.int/ respiratory/copd/en/ 2015 accessed at 25-8-2018.

2. Rizvi N. COPD is the leading cause of death. Pulse Intern Fortnightly Med News Paper, 2010; 1-14.

3. Beran D, Zar HJ, Perrin C, Menezes AM, Burney P, Forum of International Respiratory Societies working group c. Burden of asthma and chronic obstructive pulmonary disease and access to essential medicines in low-income and middleincome countries. The Lancet Respiratory medicine 2015; 3(2): 159-70.

4. Eisner MD,Anthonisen N,Coultas D,Kuenzli N,Perez-Padilla R,Postma Det al. An Official American Thoracic Society Public Policy Statement: Novel Risk Factors and the Global Burden of Chronic Obstructive Pulmonary Disease. Am J RespirCrit Care Med 2010; 182:693-718.

5. de los MonterosEMJ, Pena C, Soto Hurtado EJ, Jareno J, Miravitles M. Variability of respiratory symptoms in severe COPD. Arch Bronchoneumol 2012; 48:3-7.

6. National Heart, Lung and Blood Institute. Morbidity and mortality 2012 chartbook on cardiovascular, lung and blood diseases. Bethesda, Maryland: US Department of Health and Human Services, Public Health Service, National institute of Health. Available at:http://www.nhlbi.nih.gov/ files/docs/ research/2012_Chart Book_508.pdf; Accessed at 25-6-2015.
7. Zwar NA, Marks GB, Hermiz O, Middleton SS, Comino EJ, Hasan I et al. Predictors of accuracy of diagnosis of chronic obstructive pulmonary disease in general practice. Med J Aust., 2011; 195:168-171.

8. Cazzola M, Page CP, Calzetta and Matera MG. Pharmacology and Therapeutics of Bronchodilators. Pharmacological Reviews 2012; 64:450-504.

9. Kew KM, Mavergames C, Walters JA. Long-acting beta2agonists for chronic obstructive pulmonary disease. Cochrane Database Syst Rev 2013; 10(10): CD010177.

10. Geake JB, Dabscheck EJ, Wood-Baker R, Cates CJ. Indacaterol, a once-daily beta2-agonist, versus twice-daily beta(2)-agonists or placebo for chronic obstructive pulmonary disease. Cochrane Database Syst Rev 2015; 1: CD010139.

11. Melani AS. Long-acting muscarinic antagonists. Expert Rev ClinPharmacol., 2015; 8(4):479-501.

12. Singh D,Papi A,Corradi M,Pavlišová I,Montagna I,Francisco Cet al. Single inhaler triple therapy versus inhaled corticosteroid plus long-acting beta2-agonist therapy for chronic obstructive pulmonary disease (TRILOGY): a double-blind, parallel group, randomised controlled trial. Lancet 2016; 388(10048): 963-73.

13. Brusasca V. Reducing cholinergic constriction: the major reversible mechanism in COPD. EurRespir Rev 2006; 15:326.

14. Oenema TA et al. Pro-inflammatory mechanisms of muscarinic receptor stimulation in airway smooth muscle. Respir Res., 2010; 11:130.

15. Belmonte KE. Cholinergic pathways in the lungs and anticholinergic therapy for chronic obstructive pulmonary disease. Proc Am ThoracSoc 2005; 2:297-304.

16. Barnes PJ. Theophylline for COPD. Thorax. 2006; 61:742-744.

17. Cosio MG, Saetta M, and Agusti A. Immunologic Aspects of Chronic Obstructive Pulmonary Disease N Engl J Med 2009; 360:2445-2454.

18. Barnes PJ, Agusti A. Low-dose theophylline enhances the anti-inflammatory effects of steroids during exacerbations of COPD. Thorax 2009; 64:424-429.

19. [Gold] Global Initiative for Chronic Obstructive Lung Disease. Global strategy for the diagnosis, management, and prevention of chronic obstructive pulmonary disease, Updated 2013. Available at:http://www.goldcopd. com Accessed at 25-82018.

20. Husebo G, Köll R, et al. CAT-score is a predictor for mortality in COPD. European Respiratory Journal 2016 48: 3106.

21. Marwick JA, Caramori G, Casolari P, Mazzoni F, Kirkham PA, Adcock IM, Chung KF, Papi A. A role for phosphoinositol 3-kinase delta in the impairment of glucocorticoid responsiveness in patients with chronic obstructive pulmonary disease. J Allergy ClinImmunol. 2010; 125:1146-53.

22. Jones PW1, Brusselle G, Dal Negro RW, Ferrer M, Kardos $\mathrm{P}$, et al. Properties of the COPD assessment test in a crosssectional European study. EurRespir J. 2011; 38(1):29-35.

23. To M, Ito K, Kizawa Y, Failla M, Ito M, Kusama T, et al. Targeting phosphoinositide-3-kinase-ä with theophylline reverses corticosteroid insensitivity in COPD. Am J RespirCrit Care Med. 2010; 182:897-904. 
Muzna Hameed Dar, Syed Mehboob Alam, Qurrat ul Ain Bukhari, Kauser Ismail, Syed Azhar Hussain Zaidi

24. Bellia V, Foresi A, Bianco S, Grassi V, Olivieri D, Bensi G and Volonte M. Efficacy and safety of oxitropium bromide, theophylline and their combination in COPD patients: a double-blind, randomized, multicenter study (BREATHTrial). Respir Med 2002; 96:881- 889.

25. Augusti A, Calverly PMA, Celli B, Coxson HO, Edwards LD, Lomas DA, MacNee W, Miller BE, Rennard S, Silverman EK, Tal-Singer R, Wouters E, Yates JC, Vestbo J. Characterisation of COPD heterogeneity in the ECLIPSE cohort. Respir Res 2010; 11:122.

26. Devereux G, Cotton S, Fielding S, McMeekin N, Barnes PJ, Briggs A, Burns G, Chaudhuri R, Chrystyn H, Davies L, et al. Low-dose oral theophylline combined with inhaled corticosteroids for people with chronic obstructive pulmonary disease and high risk of exacerbations: a RCT. Health Technol Assess. 2019 Jul; 23(37):1-146
27. Freeman D, Lee A, Price D. Efficacy and safety of tiotropium in COPD patients in primary care- the SPiRiva Usual Care (SPRUCE) study. Respir Res 2007; 8:45.

28. Tashkin DP, Celli B, Senn S, et al. A 4-year trial of tiotropium in chronic obstructive pulmonary disease. N Engl J Med 2008; 359:1543-1554.

29. Ford PA, Durham AL, Russell RE, Gordon F, Adcock IM, Barnes PJ. Treatment effects of low-dose theophylline combined with an inhaled corticosteroid in COPD. Chest. 2010; 137(6):1338-44. 